\title{
Pengaruh Tingkat Aksesibilitas Mobil Penumpang Umum Terhadap Perkembangan Ekonomi Masyarakat Di Kabupaten Sikka Provinsi NTT
}

\author{
Alfridus Gado ${ }^{1, *}$, Ismiyati Ismiyati ${ }^{1}$, Mudjiastuti Handajani ${ }^{1}$ \\ Prodi Magister Teknik Sipil, Universitas Diponegoro, Semarang ${ }^{1}$ \\ Koresponden*, Email: alfridusg@gmail.com
}

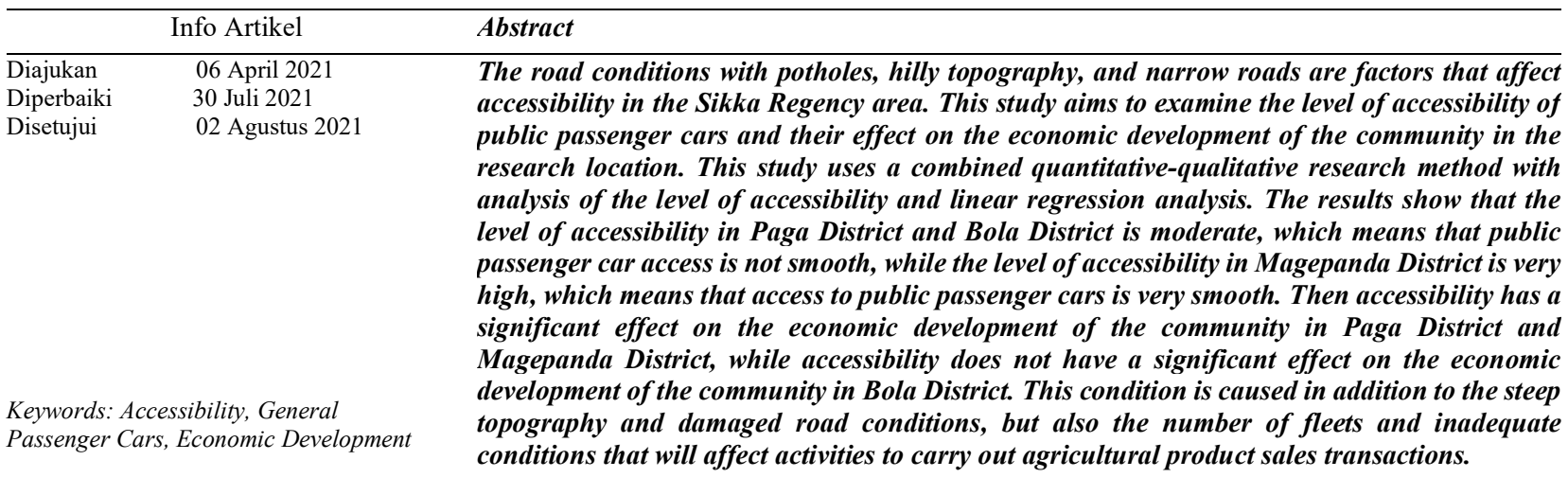

\begin{abstract}
Abstrak
Kondisi jalan yang berlubang, kondisi topografi yang berbukit dan jalan yang sempit merupakan faktor yang memepengaruhi aksesibilitas di wilayah Kabupaten Sikka. Penelitian ini bertujuan untuk mengkaji tingkat aksesibilitas mobil penumpang umum dan pengaruhnya terhadap perkembangan ekonomi masyarakat di lokasi penelitian. Penelitian ini menggunakan metode penelitian gabungan kuantitatif-kualitatif dengan analisis tingkat aksesibilitas dan analisis regresi linear. Hasil menunjukan tingkat aksesibilitas di Kecamatan Paga dan Kecamatan Bola tergolong sedang yang berarti akses mobil penumpang umum kurang lancar, sedangkan tingkat aksesibilitas di Kecamatan Magepanda tergolong sangat tinggi yang berarti akses mobil penumpang umum sangat lancar. Kemudian aksesibilitas berpengaruh signifikan terhadap perkembangan ekonomi masyarakat di Kecamatan Paga dan Kecamatan Magepanda, sedangkan aksesibilitas kurang berpengaruh signifikan terhadap perkembangan ekonomi masyarakat di Kecamatan Bola. Kondisi demikian disebabkan selain topografi yang terjal dan kondisi jalan yang rusak, namun juga jumlah armada dan kondisi yang kurang layak akan mempengaruhi aktivitas untuk melakukan transaksi penjualan hasil bumi.
\end{abstract}

Kata kunci: Aksesibilitas, Mobil Penumpang

\section{Pendahuluan}

Meningkatnya pertumbuhan penduduk dan ekonomi masyarakat menyebabkan jumlah fasilitas umum dan sistem perangkutan serta perjalanan yang dilakukan oleh individuindividu atau kelompok semakin meningkat, sehingga lalu lintas dan perangkutan tidak dapat dipisahkan dari kehidupan manusia dalam pergerakan manusia itu sendiri maupun komponen kecil dari suatu perekonomian.

Aksesibilitas merupakan suatu ukuran kenyamanan atau kemudahan pencapaian lokasi dan hubungannya satu sama lain, mudah atau sulitnya lokasi tersebut dicapai melalui transportasi [1]. Transportasi merupakan kebutuhan turunan dari kegiatan ekonomi, pertumbuhan ekonomi suatu negara atau wilayah tercermin pada peningkatan transportasinya. Salah satu jenis jaringan transportasi yang paling mendasar adalah jaringan transportasi darat yang dalam hal ini adalah infrastriktur jalan. Daerah-daerah di Indonesia memang masih dikuasai oleh moda transportasi yang menggunakan prasarana jalan [2].

Wilayah Kabupaten Sikka merupakan salah satu wilayah yang terletak di Pulau Flores, Provinsi Nusa Tenggara Timur. Wilayah tersebut memiliki banyak kekayaan alam dan budaya yang menarik, namun masih tersembunyi karena kurangnya pembangunan infrastruktur. Kondisi tersebut mempengaruhi aksesibilitas kendaraan mobil penumpang umum terhadap perkembangan ekonomi masyarakat yang berada di Wilayah Kabupaten Sikka. Tingkat kemiskinan penduduk di Wilayah Kabupaten Sikka adalah sebesar 50\% dari jumlah keseluruhan penduduk di Kabupaten Sikka [3]. Adapun faktor-faktor yang berpengaruh pada aksesibilitas kendaraan 
mobil penumpang umum diantaranya kondisi jalan yang sempit, klasifikasi jalan negara, jalan provinsi dan jalan kabupaten yang kurang seimbang, tata guna lahan, waktu tempuh yang lama dan jarak dari desa ke daerah perkotaan yang jauh.

Keberadaan infrastruktur jalan yang memiliki tingkat pelayanan yang baik penting peranannya dalam mengalirkan komoditas yang selanjutnya mampu menggerakan kehidupan sosial dan meningkatnya kemampuan ekonomi masyarakat. Infrastruktur adalah roda penggerak pertumbuhan ekonomi. Ketidakcukupan infrastruktur merupakan salah satu kunci terjadinya hambatan bagi pertumbuhan ekonomi yang lebih cepat [4].

Penelitian yang sudah dilakukan sebelumnya variabel waktu tunggu angkutan umum, waktu perjalanan angkutan umum dan waktu pejalan kaki berpengaruh terhadap indeks aksesibilitas [5]. Beberapa faktor yaitu jenis kelamin, usia, tingkat pendapatan, kepemilikan SIM, tingkat pendidikan, waktu, jarak dan biaya perjalanan berpengaruh signifikan terhadap pemilihan moda angkutan umum oleh mahasiswa [6]. Beberapa variabel yaitu jumlah penduduk, jarak ke tempat tujuan, moda utama, kapasitas moda, frekuensi moda, akses ke prasarana, kondisi sarana dan prasarana, serta waktu dan biaya perjalanan berpengaruh signifikan terhadap indeks aksesibilitas dan sangat tepat untuk perecanaan yang terpa$\mathrm{du}$, terintegrasi yang disesuaikan dengan karakteristik daerah [7].

Infrastruktur panjang jalan, kesehatan, pendidikan, konsumsi listrik, tenaga kerja pengeluaran pembangunan dan PDRB berpengaruh signifikan terhadap pertumbuhan ekonomi daerah [8]. Pembangunan jalan berdampak positif terhadap akses dan pertumbuhan usaha ekonomi rakyat [9]. Angka keterkaitan rata-rata yang di dapat dari matrix jarak tempuh terpendek antar Kota/Kabupaten menjadi pembanding tingkat aksesibilitas [10]. Variabel jumlah penduduk, jarah antara pusat - hinterland serta ketersediaan infrastruktur ekonomi seperti toko, industri, rumah makan, bank, pasar, pasar hewan, hotel, stasiun dan terminal berpengaruh terhadap tingkat aksesibilitas dan pelayanan daerah [11]. Waktu tunggu rata-rata dan biaya perjalanan berpengaruh terhadap aksesibilitas dan tingkat pelayanan angkutan umum [12]. Variabel pembangunan, income, mobilitas, aksesibilitas, kepadatan penduduk, dan kepadatan aktivitas masyarakat berpengaruh terhadap konsep kebijakan penanganan aksesibilitas yang berkelanjutan pada kawasan pedesaan, sehingga masyarakat pedesaan memiliki kemampuan untuk keluar dari perangkap kemiskinan [13]. Variabel konektivitas, aksesibilitas dan kualitas layanan transportasi umum adalah parameter penentu penggunaan transportasi umum [14]. Beberapa dimensi yaitu dimensi ekonomi, sosial, lingkungan, kelembagaan dan hukum dapat mewujudkan aksesibilitas angkutan umum berkelanjutan [15].

Dari beberapa penelitian yang sudah pernah dilakukan, fokus penelitian ini untuk mengkaji tingkat aksesibilitas mobil penumpang umum (MPU) dan pengaruhnya terhadap perkembangan ekonomi masyarakat yang disesuaikan dengan karakteristik daerah dan permasalahannya dengan menggunakan metode kuantitatif dan kualitatif. Analisis data yang digunakan adalah analisis regresi linear. Penelitian ini diharapkan merekomendasikan bagi Instansi terkait dalam meningkatkan pelayanan angkutan umum yang lebih efektif dan efisien serta meningkatkan pembangunan infrastruktur jalan guna dapat meningkatkan perekonomian masyarakat di Wilayah Kabupaten Sikka.

\section{Data dan Metode \\ 2.1 Metode Penelitian}

Penelitian ini menggunakan metode penelitian gabungan kualitatif - kuantitatif. Metode penelitian gabungan merupakan metode penelitian dengan mengkombinasikan antara dua metode penelitian kualitatif dan kuantitatif dalam suatu kegiatan penelitian sehingga akan memperoleh data yang lebih komprehensif, valid, reliabel dan objektif [16].

Hipotesis penelitian ini yaitu: (1) aksesibilitas berpengaruh signifikan terhadap PDRB; dan (2) aksesibilitas berpengaruh signifikan terhadap indikator kesejahteraan masyarakat.

Lokasi penelitian ini yaitu di Kecamtan paga, Kecamatan Bola dan Kecamatan Magepanda. Banyaknya sampel pada penelitian ini adalah 384 orang. selanjutnya untuk proporsi sampel disetiap desa untuk tiap-tiap kecamatan yaitu Kecamatan Paga memperopleh 151 sampel lalu dibagi setiap desa dengan jumlah desa yang ada di Kecamatan Paga yaitu 8 Desa. Jadi, untuk masing-masing desa diambil 18,875 atau 19 sampel. Selanjutnya Kecamatan Bola memperoleh 115 sampel. Kemudian 115 sampel tersebut dibagi setiap desa dengan jumlah desa yang ada di Kecamatan Bola adalah 6 Desa. Jadi, untuk masing-masing desa diambil 19,167 atau 19 sampel. Kemudian Kecamatan Magepanda memperoleh 118 sampel dan dibagi setiap desa dengan jumlah desa yang ada di Kecamatan Magepanda adalah 5 Desa. Jadi, untuk masingmasing desa diambil 23,6 atau 24 sampel.

Teknik pengumpulan data dalam penelitian ini peneliti menggunakan penelitian lapangan (Field Research) yang meliputi observasi, kuessioner dan wawancara untuk mendapatkan data primer, penelitian kepustakaan (Library Research) untuk mendapatkan data-data sekunder seperti data 
jumlah penduduk, jumlah kendaraan mobil penumpang umum dan dokumen penting lainnya yang berkaitan dengan penelitian ini. Lebih jelasnya mengenai lokasi penelitian dan alur penelititian ini seperti pada Gambar 1 dan Gambar 2.

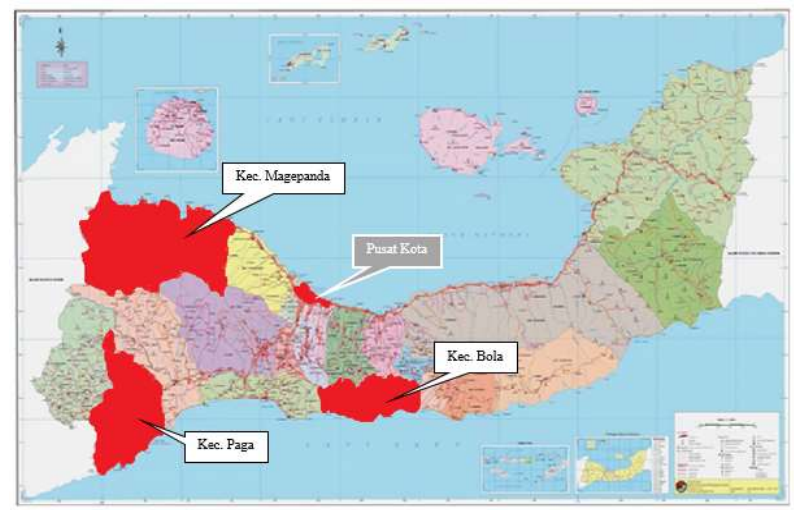

Gambar 1. Peta Lokasi Penelitian [20]

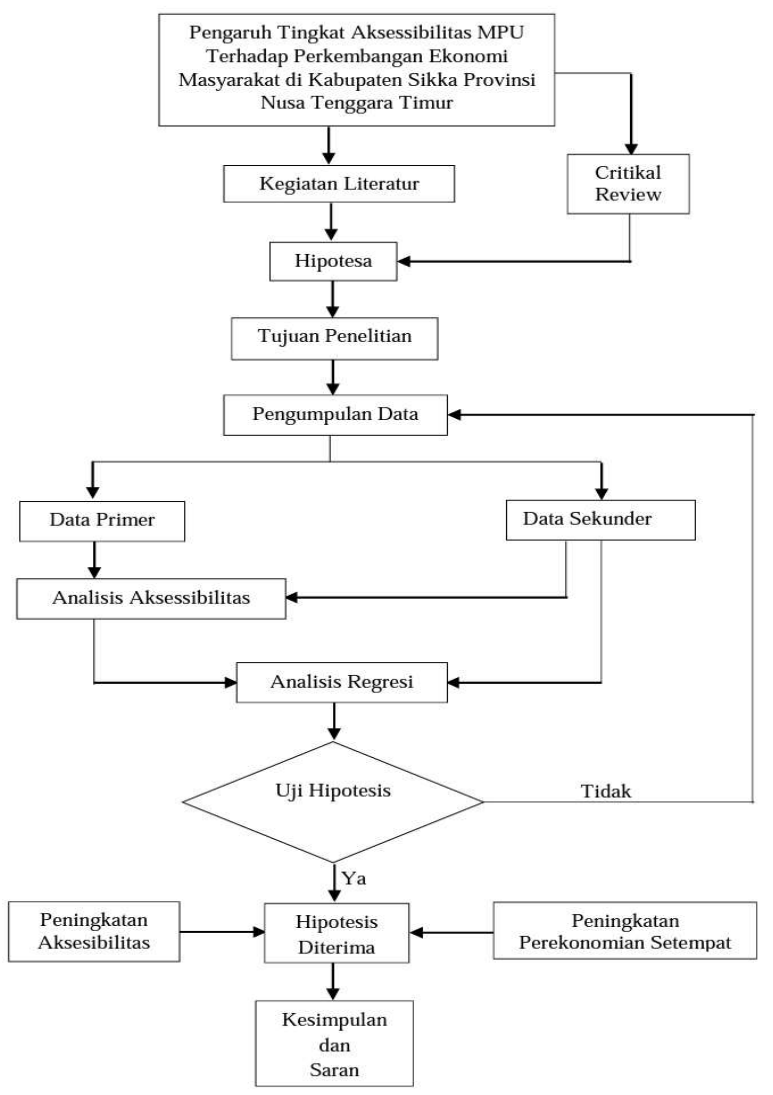

Gambar 2. Diagram Alir Penelitian

Dari Gambar 2 dapat dijabarkan tahapan dalam penelitian ini yang menggunakan penelitian kuantitaif-kualitatif adalah:
1. Menentukan topik dan masalah yang akan diteliti.

2. Landasan teori dan hipotesis. Setelah menentukan masalah peneliti mencari dan memilih teori yang relevan yang dapat digunakan untuk mendukung masalah. Kemudian menentukan hipotesis dalam penelitian ini.

3. Pengumpulan dan analisis data kuantitatif. Data yang dikumpulkan yaitu data primer dan data sekunder. Data primer meliputi data waktu tunggu kendaraan MPU, waktu pergantian moda, waktu berjalan ke rute MPU terdekat, waktu berada di dalam kendaraan MPU dan jarak ke pusat kota. Sedangkan data sekunder meliputi data jumlah penduduk yang bekerja tahun 2011-2020, jumlah penduduk di lokasi penelitian, trayek kendaraan mobil penumpang umum, data Indikator Kesejahteraan Masyarakat dan data PDRB tahun 2011 - 2020 di Kabupaten Sikka. Selanjutnya analisis data yang digunakan adalah analisis aksesibilitas dan analisis regresi.

4. Data-data yang telah diperoleh selanjutnya disusun, kemudian di uji validitas dan reabilitas data.

5. Mengelompokan catatan-catatan yang diambil dari sumber data lalu mengklasifikasinya ke dalam kelompok yang sama.

6. Melengkapi data dengan cara mengkaji isi data baik berupa hasil observasi, hasil wawancara, hasil kuessioner serta hasil dokumentasi dilapangan.

7. Analisis data. Data yang diperoleh selanjutnya di analisis dengan menggunakan analisis gabungan kuantitatifkualitatif. Analisis kuantitatif menggunakan analisis regresi linear dan analisis kualitatif berdasarkan hasil kuessioner, kemudian kajian data dijadikan jawaban setelah dianalisis.

8. Pengujian hipotesis. Pengujian hipotesis dilakukan untuk mengetahui kebenaran dari hipotesis yang dirumuskan.

9. Menyusun laporan, setelah melengkapi data dan menjabarkan jawaban secara terpernci serta pengujian hipotesis, kemudian menyususun dalam bentuk laporan dengan menarik kesimpulan dan memberikan saran.

Pengujian instrumen penelitian digunakan uji validitas dan reabilitas. Tujuan uji validitas adalah untuk mengukur tingkat kevalidan (keandalan) dari instrumen penelitian. Untuk menguji atau mengukur validitas instrumen penelitian adalah menggunakan acuan $r$ hitung $>r$ tabel, maka dinyatakan valid. Sedangkan uji reabilitas adalah uji keajegan (kestabilan) dari instrumen penelitian. Suatu variabel dikatakan reliabel jika memberikan nilai Cronbach's Alpha $>0,60$. Hasil uji validitas dan reabilitas untuk instrumen penelitian kondisi perekonomian masyarakat, aksesibilitas angkutan 
mobil penumpang umum dan indikator keberhasilan pembangunan infrastruktur jalan adalah valid dan reliabel. Sehingga, hasil kuesioner dapat digunakan untuk analisis data.

Analisis data yang digunakan dalam penelitian ini adalah analisis aksesibilitas dan analisis regresi linear menggunakan program aplikasi SPSS. Persamaan aksesibilitas sebagai berikut:

$$
A_{0}=\sum_{d} \frac{E_{d}}{t_{o d}^{b}}
$$

Dimana:

$A_{0}$ mewakili aksesibilitas zona aktual, $E_{d}$ adalah Jumlah pekerjaan di zona $d$, kemudian $t_{o d}$ adalah fungsi waktu tempuh dan $b$ adalah nilai eksponen, bila tidak diketahui nilai eksponen maka nilai eksponen yang dipakai adalah 2 (dua) [17].

Analisis regresi di gunakan untuk mendapatkan hubungan antar variabel koefisien determinasi dan koefisien korelasi dalam penelitian ini adalah hubungan antara variabel independen yaitu aksesibilitas mobil penumpang umum di wilayah Kecamatan Paga, Kecamatan Bola dan aksesibilitas mobil penumpang umum di wilayah Kecamatan Magepanda dengan perkembangan perekonomian masyarakat Kabupaten Sikka yang meliputi PDRB dan IPM sebagai variabel dependen. Model persamaannya sebagai berikut.

$\mathrm{Y}_{1}=\mathrm{b}_{0}+\mathrm{b}_{1} \mathrm{X}_{1}+\mathrm{b}_{2} \mathrm{X}_{2}$

$\mathrm{Y}_{2}=\mathrm{b}_{0}+\mathrm{b}_{1} \mathrm{X}_{1}+\mathrm{b}_{2} \mathrm{X}_{2}$

$\mathrm{Y}_{3}=\mathrm{b}_{0}+\mathrm{b}_{1} \mathrm{X}_{1}+\mathrm{b}_{2} \mathrm{X}_{2}$

Keterangan:

$\mathrm{Y}_{1}$ Aksesibilitas di Kecamatan Paga, $\mathrm{Y}_{2}$ adalah aksesibilitas di Kecamatan Bola, $\mathrm{Y}_{3}$ Aksesibilitas di Kecamatan Magepanda, $b_{0}, b_{1}, b_{2}$, adalah Konstanta, $X_{1}$ adalah PDRB di Kabupaten Sikka, $X_{2}$ adalah Indeks Pembangunan Manusia (IPM) di Kabupaten Sikka.

Untuk mengetahui besar pengaruh aksesibilitas terhadap perkembangan ekonomi masyarakat di Kabupaten Sikka, maka dilakukan pengujian statistik yaitu pengujian secara parsial (uji-t) dan pengujian koefisien determinasi diuraikan sebagai berikut.

1. Pengujian secara parsial (uji-t). Pengujian secara parsial dilakukan apabila dalam suatu penelitian mempunyai nilai eror. Dalam penelitian ini nilai eror (alpha) yang digunakan sebesar 5\%. Jika nilai probabilitas < alpha, maka terdapat hubungan yang signifikan antara variabel independen terhadap variabel dependen dan sebaliknya, jika nilai probabilitas > alpha, maka tidak terdapat hubungan yang signifikan antara variabel independen terhadap variabel dependen.

2. Pengujian koefisien determinasi. Nilai $\mathrm{R}^{2}$ berkisar antara 0 dan 1. Jika nilai $\mathrm{R}^{2}$ mendekati 1 (satu), maka pengaruh aksesibiltas mobil penumpang umum terhadap perkem- bangan perekonomian masyarakat di Kabupaten Sikka sangat besar. Begitu pun sebaliknya, jika nilai $\mathrm{R}^{2}$ mendekati 0 (nol), maka aksesibiltas mobil penumpang umum tidak berpengaruh terhadap perkembangan perekonomian masyarakat di Kabupaten Sikka.

Persamaan yang digunakan untuk menghitung koefisien determinasi di masing-masing lokasi studi sebagai berikut:

$K D=r^{2}$

$R y X_{1} X_{2}=\sqrt{\frac{r_{y x_{1}}^{2}+r_{y x_{2}}^{2}-2 r_{y x_{1}} r_{y x_{2}} r_{y x_{1} x_{2}}}{1-r_{y x_{1} x_{2}}^{2}}}$

$r_{y x_{1}}=\frac{n \sum X_{1} Y-\left(\sum Y\right)\left(\sum X_{1}\right)}{\sqrt{\left(n \sum Y^{2}-\left(\sum Y\right)^{2}\left(n \sum X_{1}^{2}-\left(X_{1}\right)^{2}\right.\right.}}$

$r_{y x_{2}}=\frac{n \sum X_{2} Y-\left(\sum Y\right)\left(\sum X_{2}\right)}{\sqrt{\left(n \sum Y^{2}-\left(\sum Y\right)^{2}\left(n \sum X_{2}^{2}-\left(X_{2}\right)^{2}\right.\right.}}$

$r_{x_{1} x_{2}}=\frac{n \sum X_{1} X_{2}-\left(\sum x_{1}\right)\left(\sum X_{2}\right)}{\sqrt{\left(n \sum X_{1}^{2}-\left(\sum X_{1}\right)^{2}\left(n \sum X_{2}^{2}-\left(X_{2}\right)^{2}\right.\right.}}$

Dimana

$K D$ adalah koefisien determinasi untuk masing-masing lokasi studi, $\mathrm{RyX}_{1} \mathrm{X}_{2}$ adalah korelasi antara $\mathrm{X}_{1}$ dan $\mathrm{X}_{2}$ bersama-sama dengan $Y . r_{y x_{1}}$ adalah korelasi product moment $\mathrm{Y}$ dengan $\mathrm{X}_{1} \cdot \mathrm{r}_{\mathrm{yx}_{2}}$ adalah korelasi product moment $Y$ dengan $\mathrm{X}_{2} . \mathrm{r}_{\mathrm{x}_{1} \mathrm{x}_{2}}$ adalah korelasi product moment $X_{1}$ dan $X_{2}$. $Y$ merupakan tingkat aksesibilitas MPU di masing-masing lokasi studi. $\mathrm{X}_{1}$ dan $\mathrm{X}_{2}$ adalah data PDRB dan IPM di kabupaten Sikka.

\subsection{Kondisi Eksisting Di Lokasi Studi}

Kecamatan Paga memliki topografi datar dan berbukit dengan rata-rata ketinggian 248 mdpl, Kecamatan Bola memiliki topografi berbukit yang curam dengan rata-rata ketinggian 269 mdpl, sedangkan Kecamatan Magepanda memiliki topografi datar dengan rata-rata ketinggian 218 mdpl. Wilayah Kecamatan Paga memiliki delapan desa yaitu Desa Paga, Desa Maulo'o, Desa Mbengu, Desa Wolowiro, Desa Lenandareta, Desa Wolowona, Desa Wolorega dan Desa Masebewa. Kemudian Wilayah Kecamatan Bola memiliki enam desa yaitu Desa Ipir, Desa Bola, Desa Wolonwalu, Desa Wolokoli, Desa Umauta dan Desa Hokor, sedangkan Wilayah Kecamatan Magepanda memiliki lima desa yaitu Desa Magepanda, Desa kolisia, Desa Kolisia B, Desa Reroroja dan Desa Done [18].

Jumlah penduduk yang paling banyak terdapat di Kecamatan Paga dengan jumlah penduduk 16.196 jiwa yang memiliki kondisi topografi datar dan perbukitan. Kemudian jumlah penduduk yang paling sedikit adalah Kecamatan Bola dengan jumlah penduduk 12.346 jiwa yang memiliki kondisi topografi perbukitan yang curam. Lebih jelasnya mengenai 
jumlah penduduk, luas daerah dan topografi dari ketiga lokasi studi dapat disajikan pada Tabel 1.

Tabel 1. Data Jumlah Penduduk, Luas Wilayah dan Topografi di Lokasi Studi [18]

\begin{tabular}{|c|c|c|c|c|}
\hline $\begin{array}{l}\text { Lokasi } \\
\text { Studi }\end{array}$ & $\begin{array}{l}\text { Jumlah } \\
\text { Penduduk } \\
\text { (Jiwa) }\end{array}$ & $\begin{array}{l}\text { Luas } \\
\text { Wila- } \\
\text { yah } \\
(\mathrm{Ha})\end{array}$ & $\begin{array}{l}\text { Keting } \\
\text { gian } \\
\text { Rata- } \\
\text { rata } \\
\text { (mdpl) }\end{array}$ & Topografi \\
\hline $\begin{array}{l}\text { Kecamatan } \\
\text { Paga }\end{array}$ & 16.196 & 82,85 & 248 & $\begin{array}{l}\text { Datar dan } \\
\text { Perbukitan }\end{array}$ \\
\hline $\begin{array}{c}\text { Kecamatan } \\
\text { Bola }\end{array}$ & 12.346 & 56,83 & 267 & $\begin{array}{c}\text { Perbukitan } \\
\text { yang } \\
\text { Curam }\end{array}$ \\
\hline $\begin{array}{l}\text { Kecamatan } \\
\text { Magepanda }\end{array}$ & 12.591 & 166,15 & 218 & Datar \\
\hline
\end{tabular}

Dilihat dari segi sosial ekonomi, penduduk Kecamatan Paga sebagian besar bekerja sebagai petani, buruh tani, nelayan dan pegawai negri sipil (PNS). Kecamatan Bola sebagian besar penduduknya bekerja sebagai petani dan buruh tani dan Penduduk di Kecamatan Magepanda sebagian besar bekerja sebagai petani, buruh tani, nelayan, peternak dan pedagang.

Jumlah armada mobil penumpang umum yang ada di lokasi studi terbanyak terdapat di Kecamatan Paga yaitu 14 unit sedangkan jumlah armada mobil penumpang umum yang paling sedikit adalah di Keamatan Bola dengan 12 unit. Jenis moda mobil penumpang umum yang melayani setiap trayek di lokasi studi adalah AKDP (Angkutan Kota Dalam Provinsi) sebagaimana pada Tabel 2.

Tabel 2. Trayek dan Jumlah MPU di Lokasi Studi [19]

\begin{tabular}{cccc}
\hline Trayek & $\begin{array}{c}\text { Kepem } \\
\text { ilikan }\end{array}$ & $\begin{array}{c}\text { Jenis } \\
\text { Moda }\end{array}$ & $\begin{array}{c}\text { Jumlah } \\
\text { Armada } \\
\text { (Unit) }\end{array}$ \\
\hline $\begin{array}{c}\text { Paga-Maumere } \\
\text { Bola-Maumere } \\
\text { Magepanda - } \\
\text { Swaumere }\end{array}$ & Swasta & AKDP & 14 \\
Swasta & AKDP & 13 \\
\hline
\end{tabular}

Hasil survei pada responden berjumlah 384 orang pengguna angkutan mobil penumpang umum yang memiliki pekerjaan sebagai petani di lokasi penelitian adalah pendapatan masyarakat, pendidikan terakhir, jenis tempat tinggal dan jumlah perjalanan masyarakat yang menggu- nakan angkutan mobil penumpang umum. Hal tersebut diperlukan untuk mengetahui karakteristik responden yang diharapkan mampu mewakili semua pengguna angkutan mobil penumpang umum di lokasi penelitian. Karakteristik responden secara terperinci dapat dilihat pada Tabel 3 dan Kondisi jalan dan kondisi mobil penumpang umum untuk masing-masing kecamatan dapat dilihat pada Gambar 3.

Tabel 3. Karakteristik Responden di Lokasi Penelitian

\begin{tabular}{|c|c|c|c|c|}
\hline \multirow[b]{2}{*}{$\begin{array}{c}\text { Karakteristik } \\
\text { Responden }\end{array}$} & \multicolumn{3}{|c|}{ Kecamatan } & \multirow[b]{2}{*}{ Jumlah } \\
\hline & Paga & Bola & $\begin{array}{c}\text { Magepa } \\
\text { nda }\end{array}$ & \\
\hline \multicolumn{5}{|c|}{ Pendapatan (Juta) } \\
\hline$<0,5$ & 42 & 65 & 13 & 120 \\
\hline $0,5-1,0$ & 93 & 46 & 26 & 165 \\
\hline $1,0-1,5$ & 16 & 4 & 72 & 92 \\
\hline$>1,5$ & - & - & 7 & 7 \\
\hline \multicolumn{5}{|c|}{ Pendidikan (Orang) } \\
\hline \multicolumn{5}{|l|}{ Sekolah } \\
\hline SD & 65 & 42 & 34 & 141 \\
\hline SMP & 36 & 24 & 38 & 98 \\
\hline SMA & 23 & 18 & 27 & 68 \\
\hline Diploma & - & - & - & - \\
\hline Sarjana & - & - & - & - \\
\hline \multicolumn{5}{|c|}{ Jenis Tempat Tinggal (Buah) } \\
\hline Permanen & 42 & 23 & 46 & 111 \\
\hline Semi & 46 & 47 & 51 & 114 \\
\hline \multicolumn{5}{|l|}{ Permanen } \\
\hline Kayu & 34 & 19 & 7 & 60 \\
\hline Bambu & 29 & 26 & 14 & 69 \\
\hline \multicolumn{5}{|c|}{ Perjalanan Dalam Satu Bulan (Trip) } \\
\hline$\leq 1$ & 42 & 57 & 17 & 116 \\
\hline $2-3$ & 46 & 32 & 22 & 100 \\
\hline $4-5$ & 34 & 21 & 27 & 82 \\
\hline$>5$ & 29 & 5 & 52 & 86 \\
\hline \multicolumn{4}{|c|}{ Jumlah untuk masing-masing karakteristik } & 384 \\
\hline
\end{tabular}

Dilihat dari Pendapatan responden, Kecamatan Paga, Kecamatan Bola dan Kecamatan Magepanda. Kemiskinan absolut adalah kondisi dimana tingkat pendapatan seseorang tidak cukup untuk memenuhi kebutuhan pokoknya seperti pangan, sandang, papan, kesehatan dan pendidikan [20]. Masyarakat di Kecamatan Paga sebagian besar memiliki pendapatan antara Rp.500.000 - Rp.1.000.000, hal ini menandakan bahwa sebagian besar masyarakat di Kecamatan Paga tergolong miskin karena dari pendapatan yang ada hanya untuk memenuhi kebutuhan pokok berupa pangan, sandang dan kesehatan. kemudian sebagian besar masyarakat di Kecamatan Bola memiliki pendapatan $<$ Rp.500.000, hal ini menandakan bahwa sebagian besar masyarakat di Kecamatan Bola tergolong sangat miskin karena dari pendapatan yang ada, tidak mencukupi untuk memenuhi kebutuhan pokok. sedangkan sebagian besar masyarakat di Kecamatan Magepanda memiliki pendapatan Rp.1.000.000 - Rp.1.500.000, hal ini menandakan bahwa sebagian besar masyarakat di 
Kecamatan Magepanda tergolong sedang karena dari pendapatan yang ada, dapat memenuhi kebutuhan pokok berupa sandang, pangan, papan, pendidikan, dan kesehatan.
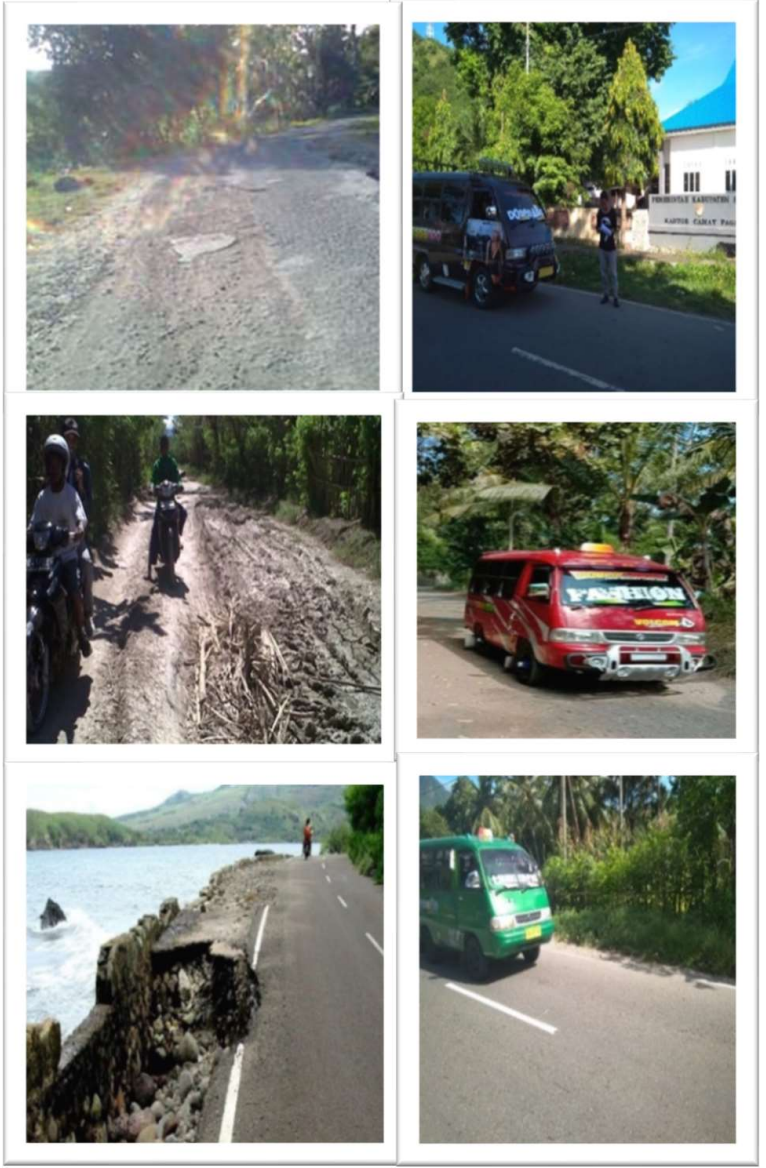

Gambar 3. Kondisi Jalan Desa Lenandareta, Kecamatan Paga; Kerusakan jalan Desa Hokor, Kecamatan Bola dan Kerusakan jalan Desa Kolisia Kecamatan Magepanda

Dilihat dari jenis tempat tinggal, jenis tempat tinggal responden yang ada di lokasi penelitian adalah permanen, semi permanen, kayu, dan bambu. Jenis tempat tinggal yang paling dominan yang ditempati oleh responden di lokasi penelitian yaitu rumah semi permanen. Kemudian dilihat dari jumlah perjalanan responden, perjalanan responden dalam 1 (satu) bulan di Kecamatan Paga, Kecamatan Bola dan Kecamatan Magepanda. Masyarakat di Kecamatan Paga sebagian besar memiliki perjalanan dalam 1 bulan adalah sebanyak $2-3$ trip, kemudian sebagian besar masyarakat di Kecamatan Bola perjalanan dalam 1 bulan adalah $\leq 1$ trip, sedangkan sebagian besar masyarakat di kecamatan Magepanda perjalanan dalam 1 bulan adalah $>5$ trip.

\subsection{Produk Domestik Bruto (PDRB) dan Indeks Pemba- ngunan Manusia (IPM) di Kabupaten Sikka}

PDRB atas dasar harga konstan untuk mengukur pertumbuhan ekonomi dan Indeks Pembangunan Manusia (IPM) yang mengukur tingkat kesejahteraan masyarakat di Kabupaten Sikka oleh Badan Pusat Statistik dari tahun 2011 sampai dengan tahun 2020, sebagaimana pada Tabel 4.

Dari data BPS Kabupaten Sikka, terungkap bahwa besaran harga PDRB Kabupaten Sikka atas dasar harga konstan tahun 2020 adalah sebesar 3.305.851,7 juta rupiah atau menurun sebesar 0,9\% dibandingkan pada tahun 2019 [20]. Indeks Pembangunan Manusia di Kabupaten Sikka mengalami peningkatan setiap tahunnya. Pada tahun 2011 Indeks Pembangunan Manusia di Kabupaten Sikka sebesar 59,62 yang dikategorikan rendah, kemudian pada tahun 2020 IPM di Kabupaten Sikka meningkat menjadi 71,40 sehingga dikategorikan sedang.

Tabel 4. PDRB dan IPM di Kabupaten Sikka [20]

\begin{tabular}{cccc}
\hline & \multicolumn{2}{c}{ PDRB ADHK } & \\
\cline { 2 - 3 } Tahun & PDRB & Laju & IPM \\
& $\begin{array}{c}\text { ADHK } \\
\text { (Juta } \\
\text { Rupiah) }\end{array}$ & $\begin{array}{c}\text { Pertumbuhan } \\
\text { PDRB ADHK }\end{array}$ \\
\hline 2011 & 2306318 & $4,47 \%$ & 59,62 \\
2012 & 2396480,2 & $3,91 \%$ & 60,12 \\
2013 & 2496724,8 & $4,20 \%$ & 60,84 \\
2014 & 2610995,8 & $4,56 \%$ & 61,36 \\
2015 & 2725791 & $4,40 \%$ & 61,81 \\
2016 & 2860285,7 & $4,93 \%$ & 62,42 \\
2017 & 3011129,6 & $5,27 \%$ & 63,08 \\
2018 & 3169954,4 & $5,26 \%$ & 63,89 \\
2019 & 3335134,3 & $5,21 \%$ & 64,75 \\
2020 & 3305851,7 & $5,12 \%$ & 71,40 \\
\hline
\end{tabular}

\section{Hasil dan Pembahasan}

\subsection{Kinerja Mobil Penumpang Umum di lokasi Studi}

Akses mobil penumpang umum di lokasi studi yang melayani masyarakat melewati masing-masing rute menuju pusat kota yang menjadi pusat kegiatan perekonomian di Kabupaten Sikka yaitu Kota Maumere. Mobil penumpang umum dari Kecamatan Paga melewati rute barat menuju pusat Kota Maumere, selanjutnya mobil penumpang umum dari Kecamatan Bola melewati rute timur menuju pusat Kota Maumere sedangkan mobil penumpang umum dari Kecamatan Magepanda melewati rute utara menuju pusat Kota Maumere. Lebih jelasnya dapat dilihat pada Gambar 1 dan Tabel 2. 
Dari data karakteristik responden yang berjumlah 384 orang, terdapat 330 orang melakukan perjalanan menuju pusat kota guna melakukan kegiatan ekonomi, sedangkan 54 orang lainnya melakukan perjalanan kepinggiran kota. Jumlah responden di Kecamatan Paga yang melakukan perjalanan kepusat kota yaitu 128 orang sedangkan sisanya yaitu 23 orang melakukan perjalanan ke pinggiran kota. Selanjutnya responden di Kecamatan Bola yang melakukan perjalanan kepusat kota berjumlah 95 orang sedangkan sisanya 20 orang melakukan perjalanan ke pinggiran kota. Kemudian jumlah responden di Kecamatan Magepanda yang melakukan perjalanan kepusat kota yaitu 107 orang sisanya 11 orang yang melakukan perjalanan ke pinggiran kota. Responden yang melakukan perjalanan ke pinggiran kota untuk keperluan tertentu seperti bekunjung ke keluarga dan rekreasi.

Jadwal mobil penumpang umum untuk masing-masing trayek di lokasi studi umumnya terjadwal pada pukul 08.00 pagi sampai pukul 16.00 sore waktu indonesia tengah (WITA). Frekuensi kendaraan mobil penumpang umum yang melewati masing-masing rute di lokasi studi sangat minim, frekuensi rata-rata mobil penumpang umum yang paling banyak adalah trayek Paga-Maumere dengan frekuensi kendaraan rata-rata adalah $11 \mathrm{kend} / \mathrm{jam}$. Sedangkan frekuensi rata-rata mobil penumpang umum yang paling sedikit adalah trayek Bola - Maumere dengan frekuensi kendaraan rata-rata yaitu 7 kend/jam. Hal ini menunjukan bahwa kualitas pelayanan mobil penumpang umum dari ketiga lokasi studi jika ditinjau dari segi frekuensinya belum maksimal melayani masyarakat, menurut bank dunia dimana frekuensi kendaraan maksimal perjamnya $12 \mathrm{kend} / \mathrm{jam}$. Frekuensi kendaraan mobil penumpang umum untuk masing-masing trayek di lokasi studi dapat dilihat pada Tabel 5.

Tabel 5 Frekuensi Kendaraan MPU di Lokasi Studi

\begin{tabular}{clcccc}
\hline \multirow{2}{*}{ No } & \multirow{2}{*}{ Trayek } & \multicolumn{3}{c}{ Frekuensi Kendaraan } & Rata- \\
\cline { 3 - 5 } & & Pagi & Siang & Sore & rata \\
\hline 1 & Paga-Maumere & 12 & 11 & 10 & 11 \\
2 & $\begin{array}{l}\text { Bola-Maumere } \\
\text { Magepanda - }\end{array}$ & 9 & 6 & 7 & 7 \\
3 & 10 & 8 & 9 & 9 \\
\hline Raumere & Mata-rata & & & & 9 \\
\hline
\end{tabular}

\subsection{Analisis Tingkat Aksesibilitas di Kabupaten Sikka}

Analisis tingkat aksesibilitas mobil penumpang umum di analisis berdasarkan indeks aksesibilitas dan waktu perjalanan angkutan umum pada tinjauan pustaka serta jumlah penduduk yang bekerja di lokasi penelitian yaitu di Kecamatan Paga, Kecamatan Bola dan Kecamatan magepanda. masingmasing lokasi studi tersebut memiliki beberapa zona yang terbagi dalam masing-masing desa yaitu: Kecamatan Paga terdapat 8 Zona meliputi: Zona 1 (Desa Paga), Zona 2 (Desa Mbengu), Zona 3 (Desa Wolowiro), Zona 4 (Desa Wolowona), Zona 5 (Desa Maulo’o), Zona 6 (Desa Lenandareta), Zona 7 (Wolorega), Zona 8 (Desa Masebewa); Kecamatan Bola terdapat 6 Zona meliputi: Zona 9 (Desa Bola), Zona 10 (Desa Ipir), Zona 11 (Desa Wolonwalu), Zona 12 (Desa Umauta), Zona 13 (Desa Hokor), Zona 14 (Desa Wolonkoli); dan Kecamatan Magepanda terdapat 5 Zona meliputi: Zona 15 (Desa Magepanda), Zona 16 (Desa Kolisia), Zona 17 (Desa Kolisia B), Zona 18 (Desa Reroroja), Zona 19 (Desa Done).

Hasil analisis aksesibilitas tiap kecamatan di lokasi penelitian berdasarkan jumlah pekerja dari tahun 2011 sampai dengan 2020 dan total waktu perjalanan MPU untuk setiap kecamatan yaitu Kecamatan Paga sebesar 113,75 menit, Kecamatan Bola sebesar 96,67 menit dan total waktu perjalanan Kecamatan Magepanda sebesar 79 menit. Salah satu contoh perhitungan aksesibilitas sebagai berikut: Tahun 2020, jumlah penduduk yang bekerja di Kecamatan Paga adalah 7454 orang. Waktu perjalanan dengan menggunakan mobil penumpang umum dari kecamatan paga menuju pusat kota kabupaten adalah 113,75 menit. Sehingga, diperoleh nilai Indeks Aksesibilitas di Kecamatan Paga tahun 2020 adalah sebesar 0,58 seperti dibawah ini.

$$
A_{0}=\sum_{d} \frac{E_{d}}{t_{o d}^{b}}=\frac{7454}{113,75^{2}}=0,58
$$

Selanjutnya hasil analisis aksesibilitas MPU untuk ketiga lokasi penelitian disajikan pada Tabel 6.

Berdasarkan penggolongan tingkat aksesibilitas, nilai indeks aksesibilitas dari yang terendah yaitu 0 dan yang tertinggi yaitu 1, maka nilai indeks aksesibilitas dapat dikategorikan sebagai berikut; nilai aksesibilitas $0-0,20$ dikategorikan rendah, nilai aksesibilitas 0,21 - 0,40 dikategorikan sedang, nilai aksesibilitas 0,41 - 0,60 dikategorikan menengah, nilai aksesibilitas $0,61-0,80$ dikategorikan tinggi dan untuk nilai aksesibilitas $0,81-1,00$ dikategorikan sangat tinggi [21].

Tingkat aksesibilitas di Kecamatan Paga dari tahun 2011 sampai dengan tahun 2020 untuk setiap tahunnya tingkat aksesibilitas tergolong menengah, selanjutnya tingkat aksesibilitas di Kecamatan Bola dari tahun 2011 sampai dengan tahun 2020 untuk setiap tahunnya tingkat aksesibilitas juga tergolong menengah. Sedangkan tingkat aksesibilitas di Kecamatan Magepanda dari tahun 2011 sampai dengan tahun 2020 untuk setiap tahunnya tergolong sangat tinggi.

Tingkat aksesibilitas Kecamatan Magepanda tergolong tinggi dipengaruhi oleh kondisi topografi yang datar dan sebagian besar masyarakat tergolong sedang yang memiliki 
pendapatan Rp.1.000.000 - Rp.1.500.000 yang lebih dari cukup untuk memenuhi kebutuhan pokok berupa sandang, pangan, papan, kesehatan serta pendidikan dan melakukan perjalanan ke kota $>5$ kali dalam satu bulan.

\subsection{Analisis Pengaruh Tingkat Aksesibilitas MPU terhadap Perkembangan Ekonomi Masyarakat di Kabupaten Sikka}

Aksesibilitas dalam analisis ini berupa aksesibilitas MPU dari masing-masing lokasi penelitiaan dan perkembangan ekonomi masyarakat dalam analisis ini meliputi data Produk Domestik Regional Bruto (PDRB) atas dasar harga konstan di Kabupaten Sikka tahun 2011 - 2020 dan data Indikator kesejahteraan masyarakat yang di ukur dari Indeks Pembangunan Manusia (IPM) di Kabupaten Sikka tahun 2011 2020 menggunakan analisis regresi linear dengan menggunakan persamaan (5), (6), (7), (8) dan persamaan (9).

Dari hasil analisis regresi, diperoleh koefisien determinasi di Kecamatan Paga adalah 0,915. Hal ini berarti 91,5\% aksesibilitas MPU yang tergolong menengah di Kecamatan Paga berpengaruh terhadap peningkatan PDRB dan IPM. Sedangkan sisanya $8,5 \%$ dipengaruhi oleh faktor lain diantaranya adalah kondisi perekonomian masyarakat yang tergolong miskin mempengaruhi peningkatan PDRB dan IPM di Kabupaten Sikka. Kemudian koefisien determinasi di Kecamatan Bola adalah 0,404. Hal ini berarti $40,4 \%$ aksesibilitas MPU yang tergolong menengah di Kecamatan Bola tidak berpengaruh terhadap peningkatan PDRB dan IPM. Sedangkan sisanya 59,6\% dipengaruhi oleh faktor lain diantaranya adalah kondisi perekonomian masyarakat yang tergolong sangat miskin mempengaruhi peningkatan PDRB dan IPM di Kabupaten Sikka. koefisien determinasi di Kecamatan Paga adalah 0,984. Hal ini berarti 96,4\% aksesibilitas MPU yang tergolong menengah di Kecamatan Paga berpengaruh terhadap peningkatan PDRB dan IPM. Sedangkan sisanya 1,6\% dipengaruhi oleh faktor lain diantaranya adalah kondisi perekonomian masyarakat yang tergolong hampir miskin mempengaruhi peningkatan PDRB dan IPM di Kabupaten Sikka.

Nilai probabilitas untuk Kecamatan Paga sebesar 0,000 yang berarti $<$ nilai alpha $(0,05)$, dengan demikian persamaan regresi memenuhi kriteria linearitas atau model regresi yang diperoleh adalah valid menunjukan peningkatan aksesibilitas MPU di Kecamatan Paga tergolong sedang berpengaruh signifikan terhadap peningkatan PRRB dan IPM. Selanjutnya nilai signifikan untuk Kecamatan Bola sebesar 0,164 yang berarti $>$ nilai alpha $(0,05)$, dengan demikian persamaan regresi tidak memenuhi kriteria linearitas atau model regresi yang diperoleh adalah tidak valid. Aksesibilitas MPU di kecamatan Bola yang tergolong sedang tidak berpengaruh terhadap peningkatan PDRB dan IPM di Kabupaten Sikka Kemudian nilai signifikan Untuk Kecamatan Magepanda sebesar 0,000 yang berarti < nilai alpha $(0,05)$, dengan demikian persamaan regresi memenuhi kriteria linearitas atau model regresi yang diperoleh adalah valid. Sehingga Aksesibilitas MPU di kecamatan Magepanda yang tergolong sangat tinggi berpengaruh signifikan terhadap peningkatan PDRB dan IPM di Kabupaten Sikka.

Dari hasil penyebaran kuesioner kepada 384 orang responden, bahwa sebagian besar masyarakat memiliki pekerjaan sebagai petani dengan pendapatan per bulan adalah Rp. 500.000 sampai dengan Rp. 1.000.000, kondisi rumah yang yang ditempati adalah semi permanen serta sebagian besar masyarakat di lokasi studi memiliki tingkat pendidikan SD dan SMP. Pendapatan masyarakat diperoleh dari penjualan hasil bumi yang hanya diperjualbelikan di kecamatan lokasi studi. Dengan memiliki pendapatan yang cukup, masyarakat dapat memenuhi kebutuhan hidup sehari-hari dan dapat melakukan perjalanan ke Kota walaupun 2 sampai 3 trip dalam satu bulan untuk berbelanja dengan menggunakan angkutan mobil penumpang umum (MPU). Sehingga, dengan pendapatan yang rendah, kondisi jalan yang rusak dan topografi yang terjal menyebabkan aksesibilitas menjadi tidak lancar dan menimbulkan tingkat perkembangan ekonomi masyarakat menjadi terhambat.

Waktu perjalanan kendaraan mobil penumpang umum yang lama karena kondisi mobil penumpang umum yang kurang layak dan kondisi jalan yang rusak seperti dibeberapa zona yang dibagi berdasarkan desa-desa di lokasi penelitian antara lain di Wilayah Kecamatan Paga yaitu Desa Lenandareta, Desa Wolorega, Desa Maulo'o dan Desa Masebewa. Kemudian di wilayah Kecamatan Bola yaitu Desa Ipir, Desa Hokor dan Desa Wolonwalu, selanjutnya di Kecamatan Magepanda yaitu Desa Kolisia dan Desa Done. Indikator Keberhasilan Pembangunan Infrastruktur Jalan oleh sebagai pengukuran respon aparat desa terhadap pembangunan infrastruktur jalan di lokasi penelitian menunjukan bahwa respon aparat desa terhadap tujuh indikator yaitu (1) Meningkatkan pengetahuan masyarakat tentang Dana Desa dan penggunaannya; (2) Meningkatkan partisipasi masyarakat mulai dari Musrembang desa dan pelaksanaan pembangunan desa; (3) Terjadi sinergi antara kegiatan yang dibiayai Dana Desa dengan program-program pemerintah lainnya yang ada di desa; (4) Meningkatnya swadaya masyarakat; (5) Penyerapan tenaga kerja lokal pada kegiatan pembangunan desa semakin meningkat; (6) Kelompok masyarakat penerima manfaat semakin meningkat jumlahnya; dan (7) Terjadi peningkatan pendapatan asli desa [22]. Dari ketujuh indikator yang 
diwawancarai bahwa masyarakat desa dari setiap kecamatan yaitu Kecamatan Paga, Kecamatan Bola dan Kecamatan Magepanda belum sepenuhnya berpartisipasi dalam pembangunan infrastruktur jalan di desanya masing-masing. Hal ini di tandai dengan tidak ada swadaya pada pekerjaan lokasi maupun pekerjaan fisik dalam pembangunan infrastruktur jalan, artinya dalam melakukan suatu pekerjaan untuk pembangunan desa, masyarakat di beri upah oleh pemerintah desa karena kondisi perekonomian masyarakat yang tergolong miskin. Dari penelitian yang sudah dilakukan bahwa infrastruktur panjang jalan, kesehatan, pendidikan, konsumsi listrik, tenaga kerja pengeluaran pembangunan dan PDRB berpengaruh signifikan terhadap pertumbuhan ekonomi daerah. Namun, dari hasil penelitian ini bahwa kondisi topografi dan kondisi jalan yang rusak serta tingkat pendapatan masyarakat yang rendah berpengaruh terhadap aksesibilitas MPU serta pertumbuhan ekonomi daerah.

\section{Simpulan}

Berdasarkan analisis yang telah dilakukan, dapat di simpulkan bahwa pada Kabupaten Sikka tidak semua kecamatan mempunyai aksesibilitas yang baik yang akan mempengaruhi perekonomian masyarakat seperti Tingkat aksesibilitas di Kecamatan Paga dan Kecamatan Bola yang tergolong aksesibilitas sedang, artinya bahwa aksesnya kurang lancar, sedangkan tingkat aksesibilitas di Kecamatan Magepanda tergolong aksesibilitas sangat tinggi, berarti kelancaran mobil penumpang umum aksesnya sangat lancar. Kondisi demikian disebabkan karena selain topografi yang terjal dan kondisi jalan yang rusak, namun juga jumlah armada dan kondisi yang kurang layak, kondisi masyarakat yang kurang maju dan hasil bumi hanya diperjualbelikan di kecamatan lokasi studi.

Rekomendasi dari penelitian ini bagi pemerintah setempat maupun pemerintah daerah perlu adanya peningkatan sarana mobil penumpang umum dan akses jalan penghubung, disisi lain untuk peningkatan perekonomian masyarakat di daerah lokasi studi daerah tertinggal perlu adanya penyuluhan tentang cara poemanfaatan hasil bumi di desa tertinggal lokasi studi.

\section{Daftar Pustaka}

[1] J. A. Black, "Urban Transport Planning: Theory and Practice”. London: Cromm Helm, 1981.

[2] Direktorat Jendral Bina Marga. Manual Desai Perkerasan Jalan. Kementrian Pekerjaan Umum. Semarang, 2012.

[3] Badan Pusat Statistik, Kabupaten Sikka Dalam Angka 2018. Kabupaten Sikka. 2019.
[4] B. Ndulu, Kritzinger-van Niekerk and Reinikka, "Infrastructure, Regional Integration and Growth In Sub-Saharan Africa". The National, Regional and International Challenges Fondad, The Hague, December 2005, pp. 101-121.

[5] P. A. Suthanaya, "Analisa Aksesibilitas Penumpang Angkutan Umum Menuju Pusat Kota Denpasar". Jurnal Transportasi. Universitas Udayana, Denpasar, 2009.

[6] Djakfar, Indriastuti \& Nasution, “ Mahasiswa Menuju Kampus (Sepeda Motor atau Angkutan Umum) di Kota Malang", Jurnal Rekayasa Sipil, Universitas Brawijaya Malang, vol. 4, pp. 37-51, 2010.

[7] Oktaviana, Sulistio \& Wicaksono, "Strategi Pengembangan Transportasi Antar Wilayah di Provinsi Papua Barat", Jurnal Rekayasa Sipil, Universitas Brawijaya Malang, vol. 5, pp. 180-190, 2011.

[8] R. A. Maqin, "Pengaruh Kondisi Infrastruktur Terhadap Pertumbuhan Ekonomi Di Jawa Barat”, Jurnal Trikonomika, Universitas Pasundan, Bandung, vol.10, pp. 10-18, 2011.

[9] M. Lek, dan Goreti, “Analisa Dampak Pembangunan Jalan Terhadap Pertumbuhan Usaha Ekonomi Rakyat di Pedalaman May Brat Provinsi Papua Barat”, Jurnal Ekonomi Kuantitatif Terapan, Universitas Cendrawasih, vol. 6, pp. 30-40, 2013.

[10] D. Sulistiono, \& Asparini, et., al., "Penggunaan Angka Keterkaitan Untuk Penentuan Tingkat Aksesibilitas Kota/Kabupaten di Wilayah Provinsi Kalimantan Barat", Jurnal Aplikasi Teknik Sipil. ITS Surabaya, vol. 13, pp. 1-6, 2015.

[11] Syafi'i dan Santoso, "Identifikasi Kemampuan Pelayanan Ekonomi dan Aksesibilitas Pusat Kegiatan Lokal Ngasem Di Kabupaten Kediri”, Jurnal Aplikasi Teknik Sipil, ITS, vol. 4, pp. 17-24, 2015.

[12] I. Samsudin, "Sistem Pelayanan Pada Angkutan Kota Rute Tetap dan Rute Bebas di Kota Palangkaraya", Jurnal Penelitian Transportasi Darat, Puslitbang Transportasi Darat dan Perkeretaapian, Jakarta, vol. 19, pp. 133-142, 2017.

[13] A. A. Putra dan H. Adeswastoto, "Transportasi Publik dan Aksesibilitas Masyarakat Perkotaan”, Jurnal Teknik Industri Terintegrasi, Universitas Pahlawan Tuanku Tambusai, Riau, vol. 1, pp. 55-60, 2018.

[14] Winaryo dan Manulang, "Parameter Penentu Penggunaan Transportasi Umum di Perkotaan Pati”, Jurnal Tata Loka, Universitas Diponegoro, Semarang, vol. 20, pp. 75-86, 2018. 
[15] Hermawan, Sitorus \& Machfud, et., al., "Evaluasi Keberlanjutan Aksesibilitas Angkutan Umum di Kota Sukabumi”, Jurnal Penelitian Transportasi Darat, Bogor, vol. 5, pp. 180-190, 2019.

[16] Sugiyono, Metode Penelitian Pendidikan Pendekatan Kuantitatif, Kualitatif dan $R \& D$. Bandung: Alfabeta, 2016.

[17] J. A Black,.., and M. Conroy, Accessibility Measures and the Social Evaluation of Urban Structure, The Australian National University, Canbera, 1977.

[18] Badan Pusat Statistik, Kabupaten Sikka Dalam Angka 2020, Kabupaten Sikka, 2020.
[19] Dinas Perhubungan Kabupaten Sikka, Jumlah Kendaraan di Kabupatem Sikka, Kabupaten Sikka, 2020.

[20] Badan Pusat Statistik, Kabupaten Sikka Dalam Angka 2020, Kabupaten Sikka, 2020.

[21] H. Basri, "Pengukuran Indeks Aksesibilitas di Kota Depok Dengan Gravity Model” Jurnal Rekayasa Teknologi Nusa Putra, Departemen Teknik Sipil STT Nusa Putra, Sukabumi, vol. 2, pp.54-58, 2015.

[22] A. Luthfi, "Evaluasi Keberhasilan Pelaksanaan Infrastruktur Jalan desa terkait Dengan Pendanaan Dana Desa”, Jurnal Pembangunan Wilayah dan Kota, Universitas Diponegoro, Semarang, vol.16, no.1, pp. 25-39, 2019.

Tabel 6. Indeks Aksesibilitas di Kabupaten Sikka

\begin{tabular}{cccccccccc}
\hline \multirow{2}{*}{ Tahun } & \multicolumn{3}{c}{ Jumlah Penduduk yang Bekerja } & \multicolumn{3}{c}{ Waktu perjalanan MPU (menit) } & \multicolumn{3}{c}{ Aksesibilitas MPU } \\
\cline { 2 - 10 } & \multicolumn{3}{c}{ Pecamatan } & \multicolumn{3}{c}{ Kecamatan } & \multicolumn{3}{c}{ Kecamatan } \\
\cline { 2 - 10 } & Bola & Magepanda & Paga & Bola & Magepanda & \multicolumn{2}{c}{ Paga } & Bola & Magepanda \\
\hline 2011 & 7.137 & 5.000 & 5.302 & 113,75 & 96,67 & 79,0 & 0,55 & 0,54 & 0,85 \\
2012 & 7.168 & 5.083 & 5.360 & 113,75 & 96,67 & 79,0 & 0,55 & 0,54 & 0,86 \\
2013 & 7.210 & 5.175 & 5.426 & 113,75 & 96,67 & 79,0 & 0,56 & 0,55 & 0,87 \\
2014 & 7.246 & 5.263 & 5.489 & 113,75 & 96,67 & 79,0 & 0,56 & 0,56 & 0,88 \\
2016 & 7.274 & 5.348 & 5.546 & 113,75 & 96,67 & 79,0 & 0,56 & 0,57 & 0,89 \\
2017 & 7.299 & 5.431 & 5.601 & 113,75 & 96,67 & 79,0 & 0,56 & 0,58 & 0,90 \\
2018 & 7.321 & 5.513 & 5.654 & 113,75 & 96,67 & 79,0 & 0,57 & 0,59 & 0,91 \\
2019 & 7.356 & 5.607 & 5.719 & 113,75 & 96,67 & 79,0 & 0,57 & 0,60 & 0,92 \\
\hline
\end{tabular}

